\title{
Assessment of the Challenges in Policy Implementation in the Small Scale Gold Mining Sector in Ghana - A Case Study*
}

\author{
${ }^{1}$ P. A. Eshun and ${ }^{1}$ E. Okyere \\ ${ }^{1}$ University of Mines and Technology, P.O. Box 237, Tarkwa, Ghana
}

Eshun, P. A. and Okyere, E. (2017), "Assessment of the Challenges in Policy Implementation in the Small Scale Gold Mining Sector in Ghana - A Case Study”, Ghana Mining Journal, Vol. 17, No. 1, pp. 54 - 63.

\begin{abstract}
In recent times, stakeholders in the mining sector have expressed concerns about the environmental degradation and the social impacts of uncontrolled Small Scale Mining (SSM) activities in Ghana despite the existence of legislative instruments that define the procedures required for the acquisition of licences and operations of SSM activities in the country. This paper assesses the challenges in policy implementation in the small scale gold mining sector of Ghana by reviewing policies on regularisation and environmental management. It further identifies challenges faced by small scale mining operators in adhering to laid down policies for the smooth operation of the sector and furthermore assesses the views of some principal stakeholders on the benefits and challenges of small scale mining using the Dunkwa mining district as a test case. The methods employed include: field visits to some small scale mining sites within the Dunkwa mining district; interviews and questionnaire administration; and statistical and content analysis of data. The study reveals the following factors, among others, to have contributed largely to the difficulty in regularisation, environmental and social challenges that have plagued the SSM sector: low level of education of majority of miners; bureaucracies and centralisation of licence acquisition processes; lack of sources of finance for SSM projects; lack of geological information on mineable areas; and lack of adequate knowledge of the laws and regulations on mining and environment. In addressing the challenges the following recommendations are made: decentralisation of the regularisation processes to simplify licence acquisition; adequate geological investigations should be undertaken on SSM blocked-out areas to reduce the try and error mining approach adopted by miners; and continuous education and training of miners on good mining and environmental practices.
\end{abstract}

Keywords: Small Scale Mining, Mineral Policies, Environmental Impact, Regularisation, Challenges

\section{Introduction}

Gold mining in Ghana predates the colonial era in the $15^{\text {th }}$ Century where the indigenous people used artisanal mining methods for small scale gold mining, the gold sold to foreign traders, and also made ornaments for their own uses. Legislation drafted during the colonial era led to a disincentivisation of small scale mining in favour of large-scale mining. The passing, in 1905, of the Gold Mining Products Protection Ordinance (CAP. 149) prevented indigenous Ghanaians ('Gold Coasters') from dealing in gold ore, amalgam, bullion, retorted gold, slags and concentrates. In 1932, the Mercury Ordinance was added, making it illegal for Ghanaians to own mercury (Eshun, 2005).

The small scale mining sector remained unregulated until a Small Scale Mining Project (SSMP) was initiated in 1989 to provide the institutional framework within which to implement the provisions of PNDC Law 218 which legalised small scale mining of gold in Ghana. The objectives of the regularisation of the sector were to: provide an avenue for employment generation with a view to curbing rural-urban labour drift; absorb some of the excess labour that was retrenched from large scale mines as a result of the Structural Adjustment Programme (SAP) implemented following the Economic Recovery
Programme (ERP) in the 1980's; monitor and supervise the activities of small scale miners to ensure the use of acceptable mining practices with minimum damage to the environment; provide official market for minerals to ensure maximum contribution of the sub-sector to the national economy thereby reducing the incidence of smuggling of precious minerals; and stop encroachment of small scale miners on large-scale mining concessions (Anon., 2010).

Furthermore, a properly regulated artisanal and small scale mining sector has the huge potential of boosting employment, increasing the earnings of people in the local and surrounding communities, alleviating poverty, generating revenues for local Assemblies, and contributing towards community development through implementation of Corporate Social Responsibility (CSR) projects. Small scale gold mining continues to make significant contributions to the country's foreign exchange earnings. For example, total gold production by small scale miners rose from $2.2 \%$ in 1989 to $31 \%$ of the national production in 2016. Table 1 presents gold production in Ghana from 1990 to 2016. Figs 1 and 2 respectively compare gold production from large scale mining operations and total gold production in the country to gold production from small scale mining operations. The data show the significance of the small scale gold mining sector to the economy of Ghana. 
Table 1 Gold Production in Ghana (1990-2016)

\begin{tabular}{|r|r|r|r|r|r|r|}
\hline Year & $\begin{array}{c}\text { Large } \\
\text { Scale } \\
\text { Producers } \\
\text { (oz) }\end{array}$ & $\begin{array}{c}\text { Small } \\
\text { Scale } \\
\text { Producers } \\
\text { (oz) }\end{array}$ & $\begin{array}{c}\text { Total } \\
\text { Ghana } \\
\text { Production } \\
(\mathbf{o z})\end{array}$ & $\begin{array}{c}\text { Diff (year } \\
\text { on year) of } \\
\text { Total Prod. }\end{array}$ & $\begin{array}{c}\text { \% } \\
\text { change } \\
\text { in Prod. }\end{array}$ & $\begin{array}{c}\text { \% of small } \\
\text { Scale to Total } \\
\text { Production }\end{array}$ \\
\hline 1990 & 517,818 & 17,234 & 535,052 & & & 3.22 \\
\hline 1991 & 825,114 & 15,601 & 840,715 & 305,663 & 57.13 & 1.86 \\
\hline 1992 & 976,223 & 17,297 & 993,520 & 152,805 & 18.18 & 1.74 \\
\hline 1993 & $1,222,344$ & 35,145 & $1,257,489$ & 263,969 & 26.57 & 2.79 \\
\hline 1994 & $1,338,491$ & 89,520 & $1,428,011$ & 170,522 & 13.56 & 6.27 \\
\hline 1995 & $1,581,506$ & 127,025 & $1,708,531$ & 280,520 & 19.64 & 7.43 \\
\hline 1996 & $1,474,746$ & 112,349 & $1,587,095$ & $(121,436)$ & -7.11 & 7.08 \\
\hline 1997 & $1,677,911$ & 107,097 & $1,785,008$ & 197,913 & 12.47 & 6.00 \\
\hline 1998 & $2,244,819$ & 128,334 & $2,373,153$ & 588,145 & 32.95 & 5.41 \\
\hline 1999 & $2,358,423$ & 130,833 & $2,489,256$ & 116,103 & 4.89 & 5.26 \\
\hline 2000 & $2,168,802$ & 145,662 & $2,314,464$ & $(174,792)$ & -7.02 & 6.29 \\
\hline 2001 & $2,184,313$ & 185,596 & $2,369,909$ & 55,445 & 2.40 & 7.83 \\
\hline 2002 & $2,075,954$ & 160,879 & $2,236,833$ & $(133,076)$ & -5.62 & 7.19 \\
\hline 2003 & $2,085,070$ & 221,063 & $2,306,133$ & 69,300 & 3.10 & 9.59 \\
\hline 2004 & $1,783,400$ & 246,570 & $2,029,970$ & $(276,163)$ & -11.98 & 12.15 \\
\hline 2005 & $1,913,534$ & 225,411 & $2,138,945$ & 108,975 & 5.37 & 10.54 \\
\hline 2006 & $2,095,553$ & 247,063 & $2,342,616$ & 203,671 & 9.52 & 10.55 \\
\hline 2007 & $2,239,678$ & 388,594 & $2,628,272$ & 285,656 & 12.19 & 14.79 \\
\hline 2008 & $2,378,012$ & 418,943 & $2,796,955$ & 168,683 & 6.42 & 14.98 \\
\hline 2009 & $2,564,095$ & 555,737 & $3,119,832$ & 322,877 & 11.54 & 17.81 \\
\hline 2010 & $2,624,391$ & 767,196 & $3,391,587$ & 271,755 & 8.71 & 22.62 \\
\hline 2011 & $2,642,331$ & $1,006,623$ & $3,648,954$ & 257,367 & 7.59 & 27.59 \\
\hline 2012 & $2,848,409$ & $1,464,781$ & $4,313,190$ & 664,236 & 18.20 & 33.96 \\
\hline 2013 & $2,808,405$ & $1,441,497$ & $4,249,902$ & $(63,288)$ & -1.49 & 33.92 \\
\hline 2014 & $2,851,885$ & $1,489,722$ & $4,341,607$ & 91,705 & 2.16 & 34.31 \\
\hline 2015 & $2,592,563$ & $1,025,671$ & $3,618,234$ & $(723,373)$ & -16.66 & 28.35 \\
\hline 2016 & $2,620,033$ & $1,134,635$ & $3,754,668$ & 136,434 & 3.77 & 30.22 \\
\hline & & & & & \\
\hline
\end{tabular}

(Source: Minerals Commission)

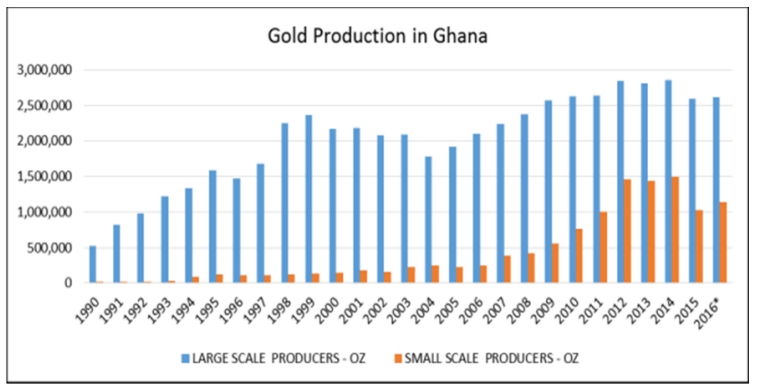

Fig. 1 Comparative Gold Production in Ghana from Large Scale and Small Scale Operations

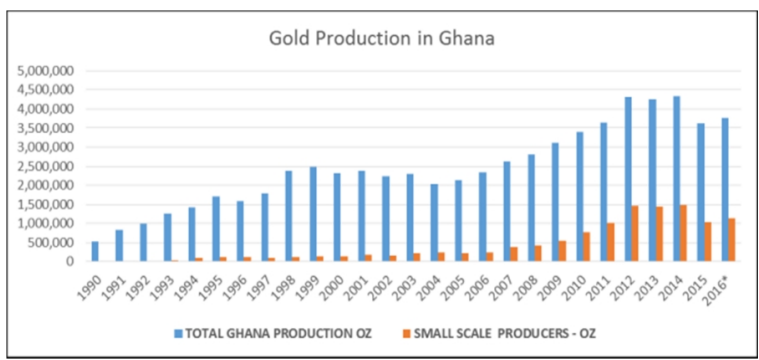

Fig. 2 Comparative Total Gold Production in Ghana and Small Scale Operations

In recent times, however, stakeholders have expressed concerns about the environmental degradation and the social impacts of uncontrolled Small Scale Mining (SSM) activities in Ghana despite the existence of legislative instruments that define the procedures required for the acquisition of licence and operations of SSM activities in the country.

The socio-economic benefits of the small scale mining sector stand to be eroded if measures are not put in place to mitigate the environmental and social challenges. It is in this context that this paper seeks to conduct an assessment of the mineral policies in the area of regularisation and environmental management on the SSM sector in Ghana using Dunkwa Mining District as a test case to identify the challenges faced by the operators in adhering to these policies and regulations, and make recommendations to address the lapses.

\subsection{Institutional Framework of Small Scale Mining in Ghana}

A number of institutions have been established to provide administrative and regulatory oversights for small scale mining operations in Ghana. The major ones include:

(i) Ministry of Lands and Natural Resources;

(ii) Minerals Commission;

(iii) Environmental Protection Agency;

(iv) Geological Survey Department;

(v) Precious Minerals Marketing Company;

(vi) Water Resources Commission; and

(vii)Forestry Commission.

\subsubsection{Ministry of Lands and Natural Resources}

The Ministry of Lands and Natural Resources (MLNR) was established under Section 11 of the Civil Service Law 1993 (PNDCL 327), and is mandated to ensure the sustainable management and utilisation of the nation's lands, forests and wildlife resources as well as the efficient management of the mineral resources for socioeconomic growth and development (Anon., 2016a).

\subsubsection{Minerals Commission}

The Minerals Commission (MINCOM) was established under Article 269 of the 1992 Constitution and the Minerals Commission Act, 1993 (Act 450). The Minerals Commission, as the main promotional and regulatory body for the minerals sector in Ghana, is responsible for the regulation and management of the utilisation of the mineral resources of Ghana and the coordination and implementation of policies relating to mining. It also ensures compliance with Ghana's Mining and Mineral Laws and Regulations through effective monitoring (Anon., 2016b).

\subsubsection{Environmental Protection Agency}

The Environmental Protection Agency (EPA) was formally established in 1994 (Act 490). It is the leading public body for protecting and improving the environment in Ghana. The EPA guides development to prevent, reduce, and as far as possible, eliminate pollution and actions that lower the quality of life (Anon., 2016c). 


\subsubsection{Geological Survey Department}

Geological Survey Department (GSD) was founded in 1913 and has since been the main repository of the country's geosciences database. GSD is responsible for the study of the country in detail to assess its resource potential (Anon., 2016d).

\subsubsection{Precious Minerals Marketing Company}

In 1989, PNDC Law 219 was enacted to change the Diamond Marketing Corporation to the Precious Minerals Marketing Corporation with the mandate to buy from small scale miners precious minerals, such as gold and diamonds, and sell precious minerals to enhance Ghana's foreign exchange earnings from the mining sector. In the year 2000, it was converted by Act 461 (Statutory Corporations Conversion to Companies Act) to a Limited Liability Company to operate under the Ghana Companies Code (Act 179 of 1963) as Precious Minerals Marketing Company Limited (Anon., 2016e). The PMMC also exists to promote the development of precious minerals and jewellery industry in Ghana by grading, assaying, valuing and processing precious minerals.

\subsubsection{Water Resources Commission}

The Water Resources Commission (WRC) was established by an Act of Parliament (Act 522 of 1996) as the overall body responsible for water resources management in Ghana. The mandate of the Water Resources Commission is specifically to regulate and manage the utilisation of water resources, and co-ordinate relevant government policies in relation to them (Anon., 2016f).

\subsubsection{Forestry Commission}

The Forestry Commission of Ghana is responsible for the regulation of the utilisation of forest and wildlife resources, the conservation and management of those resources and the coordination of policies related to them. The Commission embodies the various public bodies and agencies that were individually implementing the functions of protection, management, and regulation of forest and wildlife resources (Anon., 2016g).

\subsection{Legal and Regulatory Framework of Small Scale Mining in Ghana}

The series of laws and regulations that constitute the Ghanaian small scale mining regulatory framework are as follows:

(a) 1992 Constitution of the Republic of Ghana

(b) Minerals and Mining Act, 2006 (Act 703)

(c) Minerals and Mining Regulations, 2012

(i) General (LI 2173)

(ii) Support Services (LI 2174) (iii) Compensation \& Resettlement (LI 2175)

(iv) Licensing (LI 2176)

(v) Explosives (LI 2177)

(vi) Health, Safety \& Technical (LI 2182)

(d) Environmental Protection Agency Act, 1994 (Act 490)

(e) Environmental Assessment Regulations, 1999 (LI 1652)

(f) The Mercury Act, 1989 (PNDCL 217)

(g) Precious Minerals and Marketing Corporation (PMMC) Act, 1989 (PNDCL 219)

(h) Water Resources Act, 1996 (Act 522)

(i) Water Use Regulations, 2001 (LI 1692)

\subsubsection{Highlights of Some Legal and Regulatory} Framework

The following are highlights of some of the legal framework on mining in Ghana which relate to the regularisation and operations of small scale mining (Anon., 2006; Anon., 1994):

(i) Licence for small scale mining (Act 703, Section 82(1)), “ ... a person shall not engage in or undertake a small scale mining operation for a mineral unless there is ... a license granted by the Minister of Mines".

(ii) Qualification of applicant for small scale mining licence (Act 703, Section 83), "A licence for SSM operation shall not be granted to a person unless that person is a citizen of Ghana and has attained the age of eighteen years".

(iii) Forestry and Environmental Protection (Act 703, Section 18), “... the holder of a mineral right shall obtain the necessary approvals and permits required from the Forestry Commission and the Environmental Protection Agency for protection of natural resources, public health and the environment".

(iv) Environmental Impact Assessment (Act 490, Section 12(1)), "The agency may ... require a person responsible for an undertaking ... likely to have adverse effect on the environment to submit an environmental impact assessment".

\section{Resources and Methods Used}

Dunkwa Mining District was selected for the case study as a result of the brisk activities of illegal small scale mining and the concomitant environmental degradation. The sampling procedure adopted in this study was purposive sampling which is an example of non-probability sampling plan in selection of respondents. In all a total of one hundred and fifty (150) questionnaires were administered. Out of the total questionnaire administered, one hundred and twelve (112) were retrieved and seven were identified to be partly completed and were excluded. This resulted in a 
sample size of one hundred and five (105) that gave a response rate of $70.0 \%$. In addition, five key stakeholders were interviewed including two regulatory institutions (Minerals Commission and Environmental Protection Agency) and three community leaders (Chief of Dunkwa Traditional area, an Assembly member of Dunkwa Abankesieso electoral area (former Presiding Member of Upper Denkyira East Municipal Assembly) and Chairman of the Dunkwa Small Scale Miners' Association).

Based on the different sets of data collected (quantitative and qualitative data) this study employed two different sets of data analyses. For the quantitative data, the study employed descriptive statistics in the form of frequency distribution (Pallant, 2007) and for the qualitative data, the study employed content analysis (Bryman, 2008).

\section{Results and Discussion}

\subsection{Analysis of Data from Questionnaire}

\subsubsection{Biographic Inventory of Respondents}

Fig. 3 shows that $79 \%$ of the respondents were males with the remaining $21 \%$ being females. This clearly depicts the small scale mining sector as a male dominated industry. It can also be observed from Fig. 4 that $47 \%$ and $39 \%$ of the respondents fell within the age ranges of $31-40$ and $41-50$ years respectively, whilst $12 \%$ fell in the $18-30$ years and $2 \%$ fell in the $51-60$ years age ranges. Thus, it can be inferred that majority of the respondents $(86 \%)$ were in the active adult age of $31-50$ years.

Fig. 5 shows that $25 \%$ of the respondents had never had formal education and $35 \%$ of them had their highest level of education being primary. About $30 \%$ and $10 \%$ of respondents had their highest level of education being secondary and tertiary levels respectively. This indicates that the majority of the respondents $(60 \%)$ were either illiterates or had only basic education.

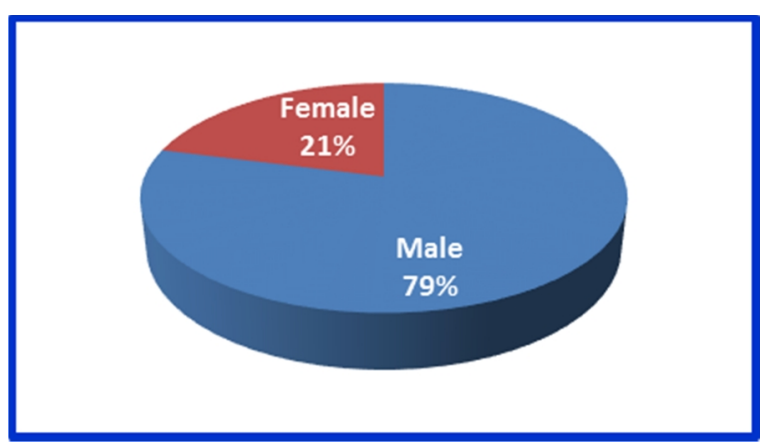

Fig. 3 Gender of Respondents

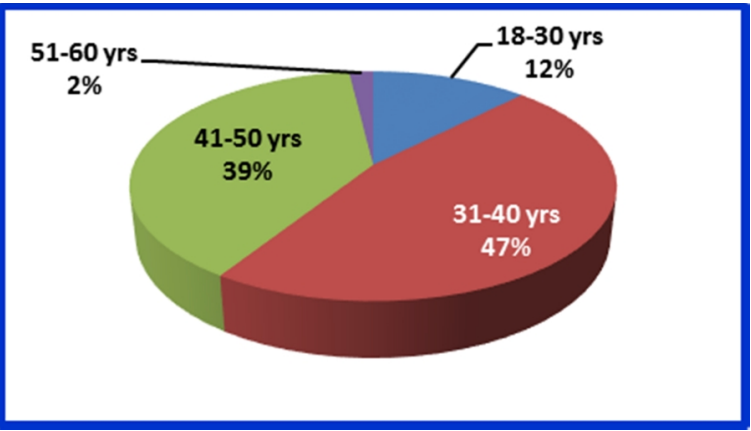

Fig. 4 Age Distribution of Respondents

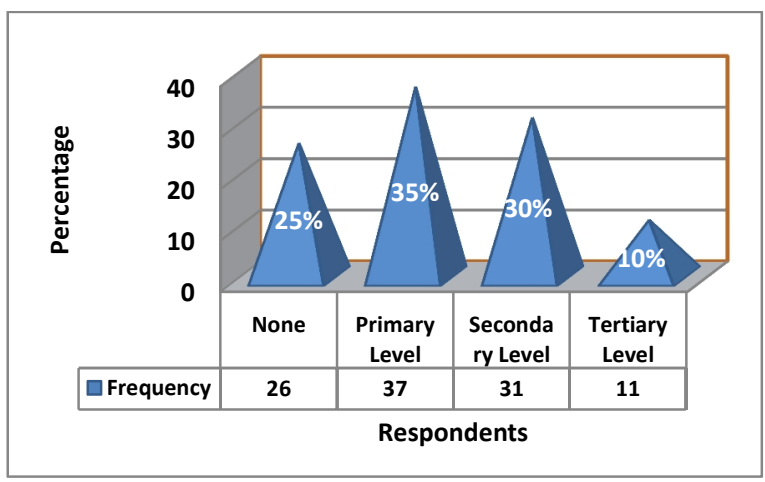

Fig. 5 Educational Level of Respondents

\subsubsection{Challenges with Regularisation}

Fig. 6 shows that $71 \%$ of respondents were not working on validly licenced concessions, with $29 \%$ of them claiming they were working on validly licenced concessions. An inference to this effect is that quite a number of the operators did not work on validly licenced concessions.

Fig. 7 reports that $89 \%$ of respondents said they had at some time applied for licence to enable them engage in small scale mining. The remaining $11 \%$ said they had never applied for small scale mining license. An inference from this is that most of the operators had at some stage in their operations applied for small scale mining licence.

The response of respondents as to whether they encountered any challenge(s) in their bid of acquiring a small scale mining licence is shown in Fig. 8. It can be observed that $86 \%$ of the respondents, who claimed to have applied for a licence, said they encountered some challenges in one way or the other. The remaining 14\% said they did not encounter any challenge(s) in the process of obtaining a valid small scale mining licence. 


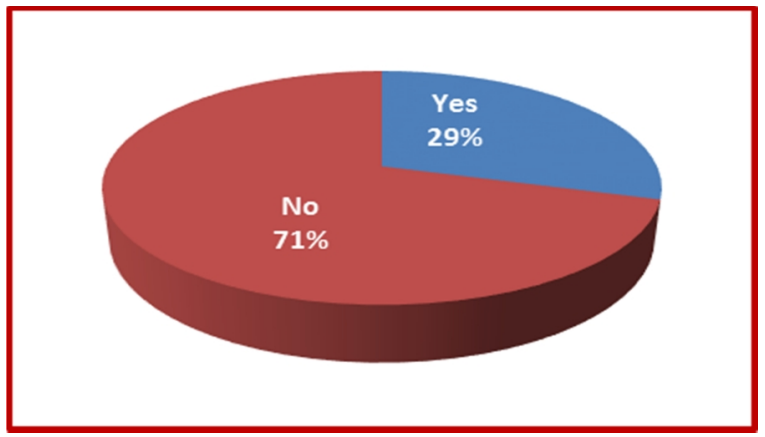

Fig. 6 Respondents Working with Valid Licences

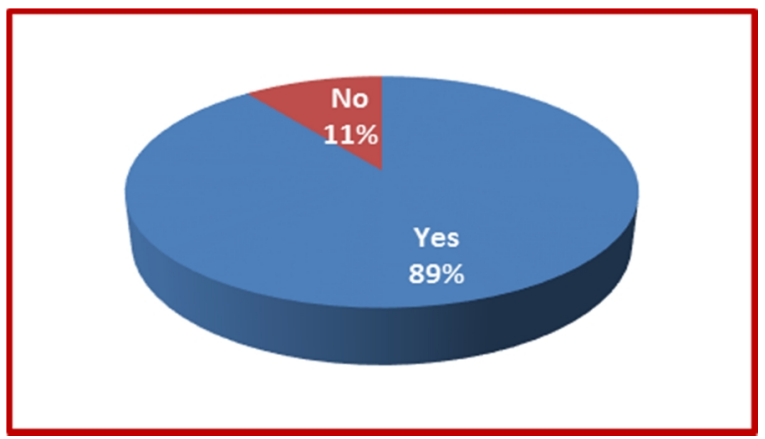

Fig. 7 Response to Licence Application

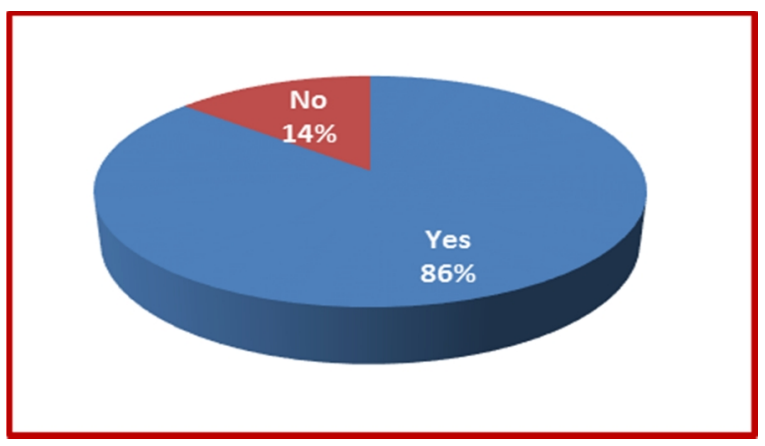

Fig. 8 Response to Challenges in Licence Applications

Some of the challenges respondents claimed to have encountered with the regularisation processes include:

(i) Delays in processing the Licence Applications at the District/Municipal Assemblies, the Minerals Commission, the EPA and the Ministry of Lands and Natural Resources;

(ii) Expensive cost of the licence to the SSM operators. Other indirect expenses incurred in following up on licences in Accra, the nation's capital, make it more expensive;

(iii) Too much bureaucracies involved in obtaining the licence;

(iv) Difficulty in getting good mineable lands to acquire for concessions; and

(v) Short permit duration of two years from the EPA as against five years of the Mining Licence granted by the Minerals Commission.

\subsubsection{Challenges with Mining Operations}

In Fig. 9, 68\% of the respondents said officials from the Minerals Commission did not visit their mining sites regularly to give them technical advice whilst the remaining $32 \%$ of the respondents on the other hand were positive in their response. It can therefore be inferred that most of the operators did not receive visits from officials of the Minerals Commission and the EPA to give them technical advice. A probable implication of this is that majority of these operators might be working using unapproved methods in their operations.

Fig. 10 reports that $98 \%$ of respondents faced a number of challenges in their mining operations. Only $2 \%$ were of the opinion that they did not encounter challenges in their mining operations.

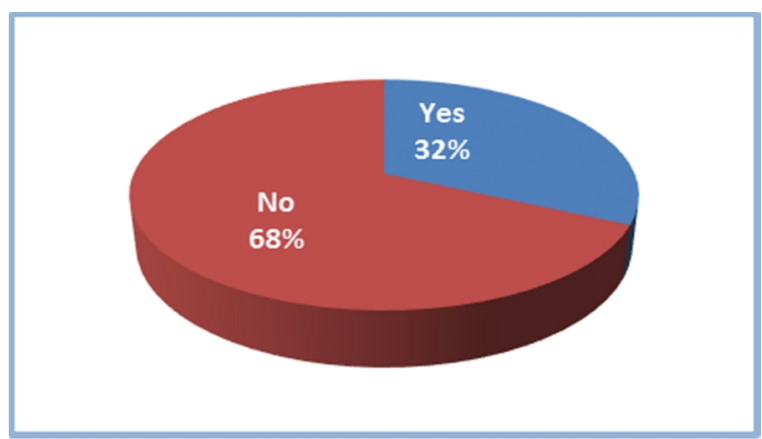

Fig. 9 Response to visits by Regulatory Institutions

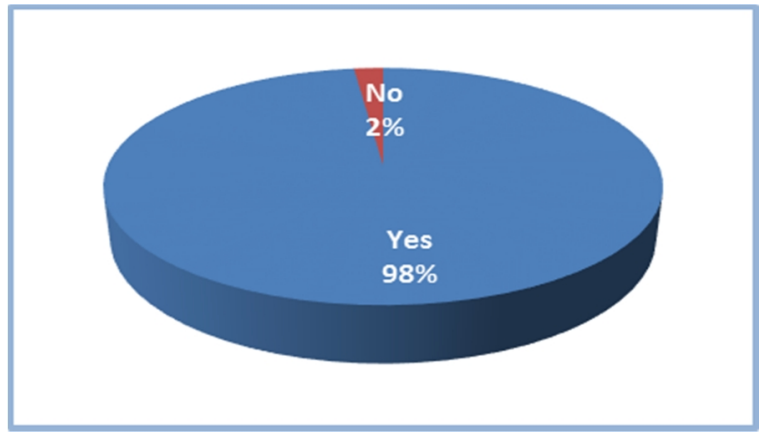

Fig. 10 Response to Challenges with Operations

The following are some challenges respondents claimed they faced during their mining operations:

(i) Lack of education on environment, health and safety issues;

(ii) Lack of geological investigations on mineable lands have reduced mining operations to try and error business leaving many excavated lands un-reclaimed;

(iii) Illegal mining operations within existing large and small scale mining concessions;

(iv) High crop and land use compensations demanded by landowners and farmers;

(v) High social responsibility demands by community leaders; example, construction of roads and clinics;

(vi) Land disputes;

(vii) Dredging in rivers and other water bodies; 
(viii) Invasion of the small scale mining sector by foreign nationals from China, India, Burkina Faso, Mali among others who engage in illegal mining;

(ix) Some communities prohibit mining operations owing to fear of land and environmental degradations;

(x) Non availability of mercury retort or direct smelting (sika bukyia) equipment on the local markets;

(xi) Lack of financial and loan facilities for small scale miners to develop and enhance their operations; and

(xii) Expensive rental and maintenance of mining equipment used for the mining operations.

\subsubsection{Challenges with Payment of Taxes and Royalties}

Fig. 11 reports that $93 \%$ of respondents said they did not pay royalties to the government. The remaining $7 \%$ were rather positive in their response that they paid royalties to the government. A deduction from this is that most of the operators did not pay royalties to the government.

Fig. 12 also shows that whilst $71 \%$ of the respondents answered "no" in their response to the payment of taxes to government, the remaining $29 \%$ however responded in the affirmative. It can, therefore, be deduced that most of the operators did not pay taxes to the government.

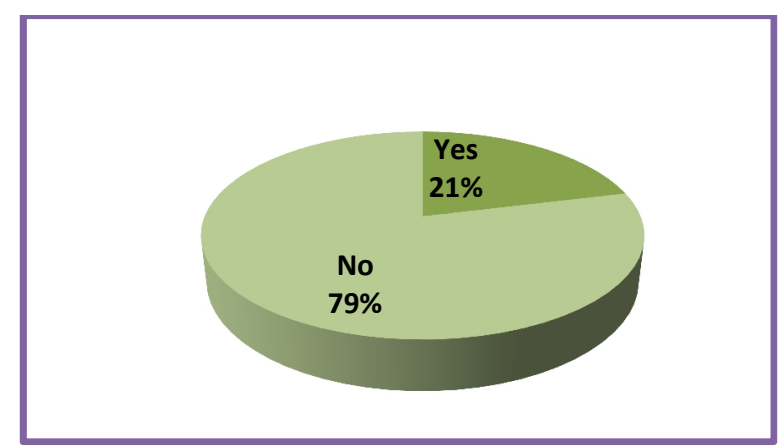

Fig. 11 Response to Payment of Royalties

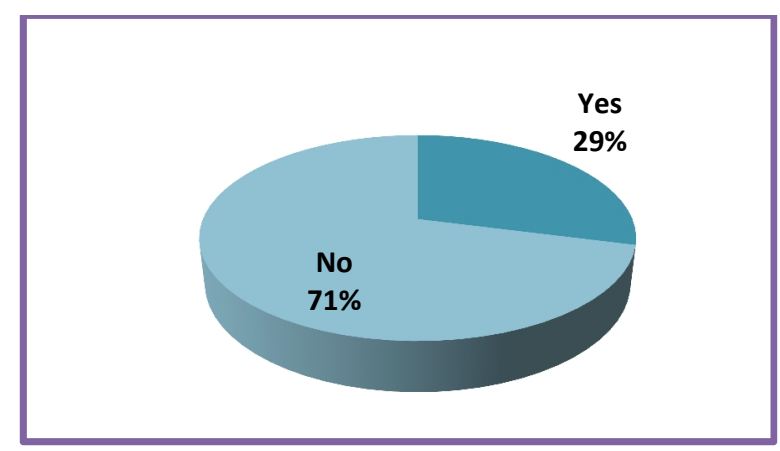

Fig. 12 Response to Payment of Taxes
Some of the reasons given for the non-payment of royalties and taxes by the respondents are as follows:

(i) They do not have adequate information and education about the payment of royalties;

(ii) They already pay huge sums of money to chiefs and land owners which they believe are some form of royalties;

(iii) They expect the Ghana Revenue Authority (GRA) to follow up in the collection of taxes;

(iv) The level of education of miners make effective record keeping very difficult, therefore how much to pay as royalty and taxes are difficult to compute; and

(v) Moreover, most of the respondents did not know how much to pay and where to pay.

\subsubsection{Knowledge of Mining and Environmental Laws and Regulations}

In Fig. 13, 92\% of respondents said they were not adequately informed about the mining, environmental laws and regulations regarding small scale mining. The remaining $8 \%$ of miners however said they were adequately informed about the mining, environmental laws and regulations regarding small scale mining. An inference is that a vast majority of the operators were not adequately informed about the mining, environmental laws and regulations regarding small scale mining.

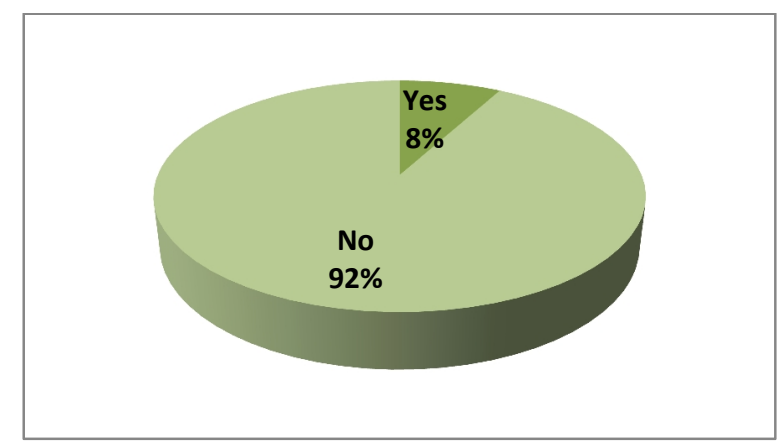

\section{Fig. 13 Knowledge of Mining, Environmental Laws and Regulations}

\subsubsection{Identification of Environmental Impacts}

On the impact of mining activities on the environment, all respondents said their activities had some negative impact. Fig. 14 ranks the types of environmental impacts from the mining operations of respondents.

It can be seen from Fig. 14 that loss of vegetation $(98 \%)$, and river and stream pollution (97\%) ranked highest followed by land degradation $(92 \%)$, mercury pollution $(73 \%)$ and noise pollution (59\%).

In Fig. 15, 92\% of the respondents said they did not undertake concurrent reclamation in their mining operations. The remaining $8 \%$ of respondents 
claimed they undertook concurrent reclamation in their mining operations. An inference from this is that majority of the operators did not undertake concurrent reclamation in their mining operations.

Fig. 16 reports on the causes of the negative environmental impacts of small scale mining as perceived by respondents. From the responses, it can be inferred that the three most predominant causes of the negative environmental impacts of small scale mining are lack of education and training of miners $(84 \%)$, lack of information on best practices $(77 \%)$, and low capital base of miners $(66 \%)$.

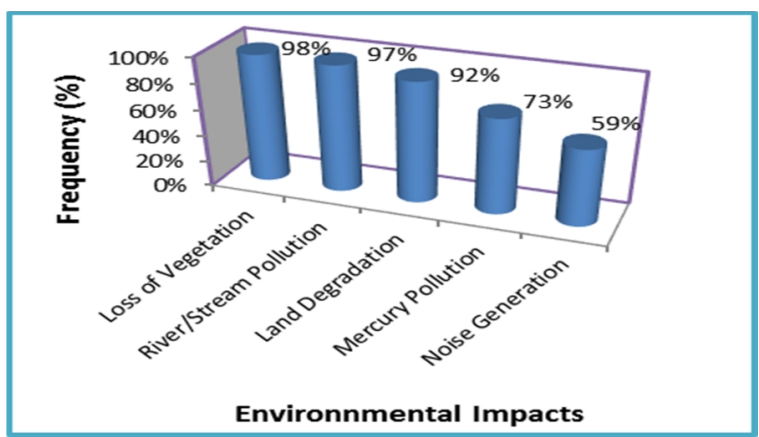

Fig. 14 Ranking of 5 Top Environmental Impacts

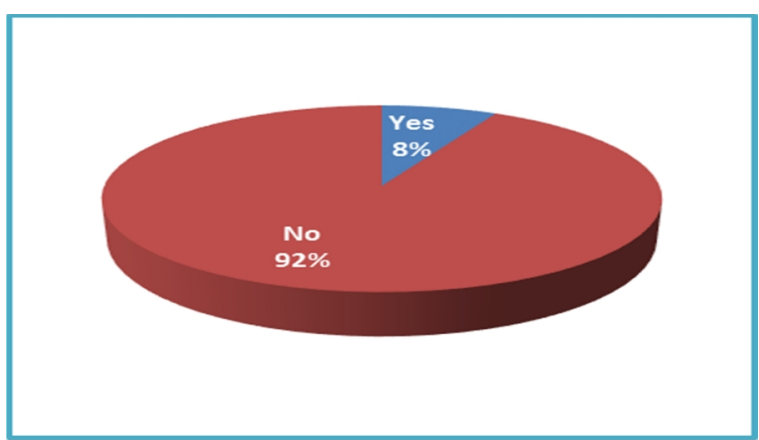

Fig. 15 Response to Concurrent Reclamation with Mining

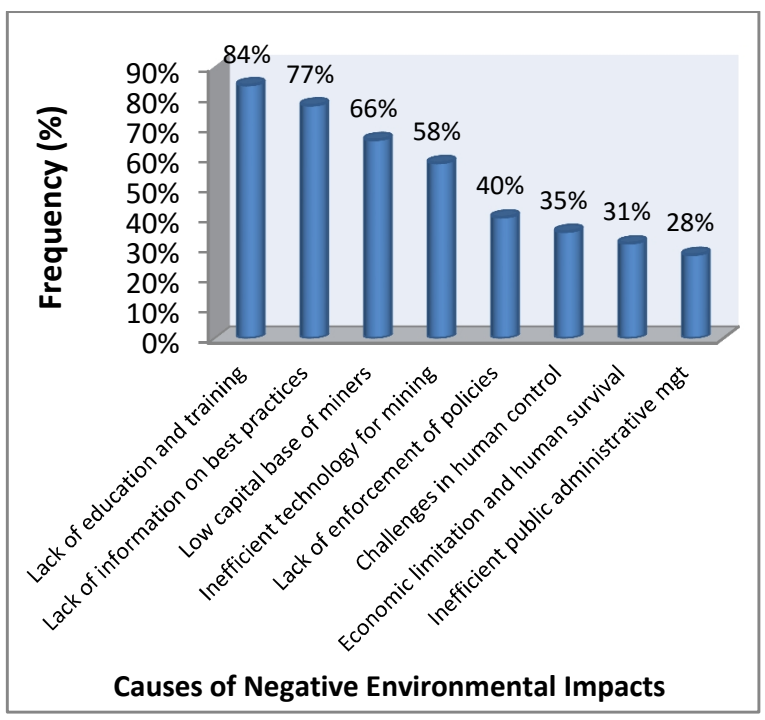

Fig. 16 Causes of Negative Environmental Impacts

\subsection{Analysis of Results from Interviews}

The study further used semi-structured interviews to obtain primary data from five key stakeholders. The stakeholders interviewed were the Officers of the Minerals Commission and Environmental Protection Agency (EPA), Chief of Dunkwa Traditional area, the Assembly member of Dunkwa Abankesieso electoral area (former Presiding Member of Upper Denkyira East Municipal Assembly) and Chairman of the Dunkwa Small Scale Miners' Association.

The stakeholders interviewed were asked whether the small scale mining operations in Dunkwa have been beneficial or otherwise. All the five key stakeholders answered unequivocally that the mining operations within the Dunkwa community have been very beneficial.

The stakeholders outlined the following benefits the mining operations have brought to the Dunkwa mining area:

(i) The provision of direct and indirect jobs for the people of Dunkwa and its surrounding villages;

(ii) Contribution to the Municipal Assembly's internally generated funds;

(iii) Improvement in the local economy of Dunkwa, thus enhancing the purchasing power of the local people; and

(iv) Financial empowerment of miners to undertake development projects such as hotels, schools, hospitals, fuel stations, Frequency Modulation (FM) stations and a number of housing projects.

Four out of the five stakeholders interviewed were very quick to add that although the mining operations have been very beneficial there are enormous challenges which include:

(i) Heavy pollution of the Offin River and its tributaries through siltation and direct dredging within the riverbeds, resulting in brown coloration of the river as shown in Fig. 17(A);

(ii) Loss of vegetation as a result of clearing the vegetation prior to construction, and excavation of overburden to gain access to the ore or gold bearing gravel as shown in Fig. 17(B); and

(iii) Environmental, health and safety issues resulting from the operations of SSM as depicted in Fig. 17(C);

(iv) Land degradations resulting from unreclaimed mined out pits, which also tend to serve as breeding grounds for mosquitoes and death traps for animals and humans;

(v) Increase in illegal mining operations;

(vi) Mercury pollution in the environment as most miners and gold buyers burn gold amalgam 
directly in open air without the use of retort or the direct smelting method;

(vii) Some small scale illegal miners have resorted to the use of fake licences; and

(viii) Some miners thrive on the ignorance of some community leaders and use single licences to mine large tracts of lands beyond even their assigned concession boundaries.

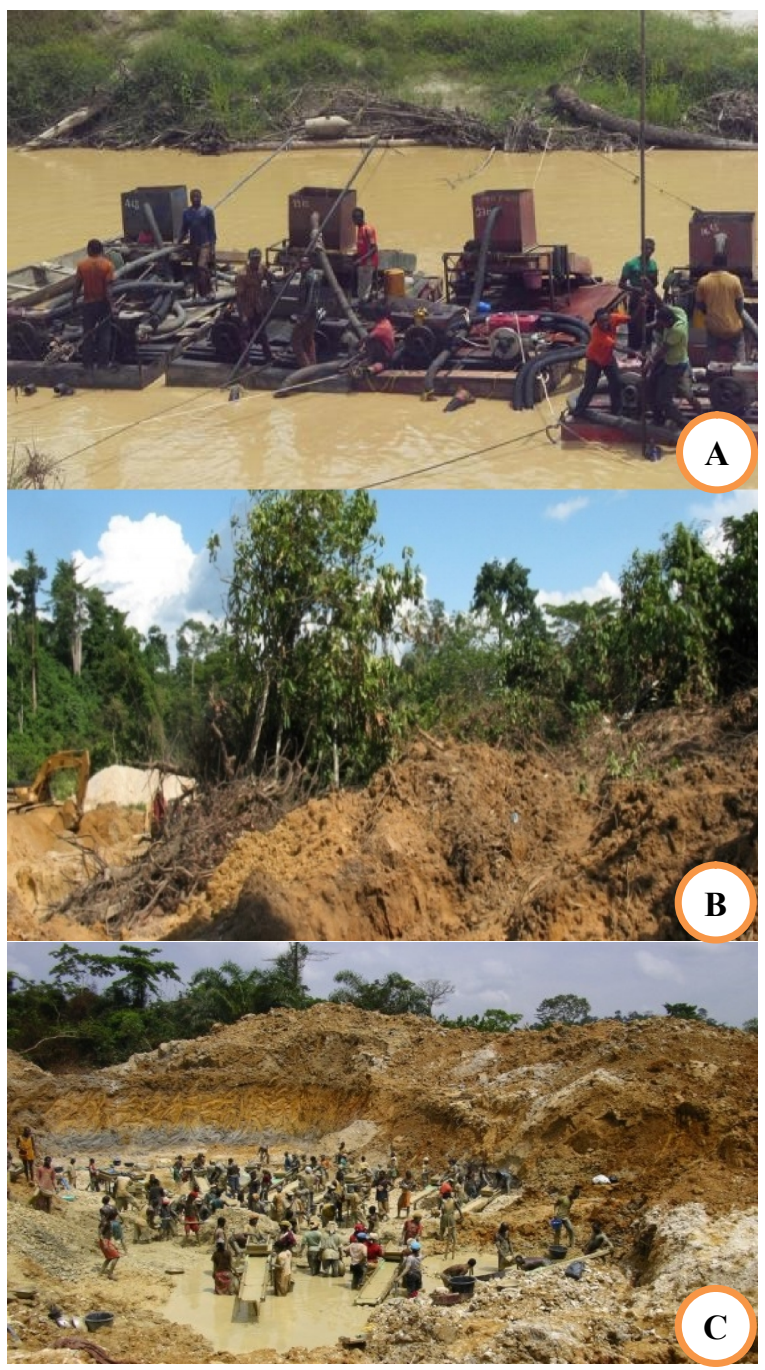

Fig. 17 Some Negative Environmental Impacts of SSM Operations in the Dunkwa Mining District

The stakeholders were asked what they thought might have accounted for the challenges faced by mining operators in adhering to mining policies and regulations in their operations at Dunkwa. Some of the responses are as follows:

(i) High level of illiteracy hindering the understanding of the need to adhere to policies and regulations;

(ii) Connivance of some traditional and opinion leaders which promotes illegal activities;

(iii) Bureaucracies in the licence acquisition procedure which delay its acquisition; (iv) Centralisation of offices for Environmental Permits and Mining Licences in the country's capital;

(v) Lack of human resources and logistics on the part of the regulatory agencies to effectively supervise and monitor activities of SSM;

(vi) Some illegal miners are heavily armed and serve as threats to regulatory institutions; and

(vii) Lack of geologically delineated areas (concessions) for SSM which has reduced mining activities to try and error, compelling miners to abandon mined out pits, following huge debts from previous workings.

\section{Conclusions and Recommendations}

In spite of Ghana's official policy to promote small scale mining as a catalyst for poverty reduction and sustainable development and various attempts to regularise the sector through series of laws and regulations, illegal mining continues to be widespread and the environmental impacts of small scale mining is still a concern.

On account of regularisation of the SSM operations in the Dunkwa Mining District, seventy-one (71) per cent of respondents were not working on validly licenced concessions. Eighty-six (86) per cent of respondents claimed to have applied for licences; however in their quest to obtain valid licences, they encountered various forms of challenges. Furthermore, sixty-eight (68) per cent of the respondents claimed the regulatory institutions such as the Minerals Commission and the Environmental Protection Agency did not visit them regularly to give them the much needed technical direction and advice. Again 79\% and $71 \%$ of respondents did not pay royalties and taxes, respectively, to the government.

The following factors amongst others have contributed largely to the difficulty in regularisation and associated environmental impacts of SSM in Ghana:

(i) Relatively low level of education of most of the miners;

(ii) Bureaucracies and centralisation of licence acquisition processes;

(iii) Lack of sources of finance for SSM projects;

(iv) Lack of geological information on mineable areas;

(v) Lack of adequate knowledge of the laws and regulations on mining and environment;

(vi) Lack of resources on the part of regulators to effectively and efficiently monitor operations of the small scale miners; and

(vii)Lack of collaboration among stakeholders.

It can therefore be concluded from the study that the low level of education of most of the people directly involved in the sector and the challenges involved in licence acquisition processes have 
accounted for the illegal mining operations. These illegal operations also invariably lead to environmental degradation and the associated challenges, as illegal miners receive very little attention by way of supervision and monitoring from regulatory institutions.

In addressing the challenges in the small scale mining sector the following recommendations are made:

(i) Decentralisation of the regularisation processes to simplify licence acquisition within the SSM sector;

(ii) Adequate geological investigations should be made on all SSM blocked-out areas to reduce the try and error approach to mining adopted by miners;

(iii) Continuous education and training of small scale miners on good mining practices and environmental impacts to help mitigate the environmental challenges;

(iv) Re-categorisation of the SSM sub-sector into Artisanal, Small scale and Medium scale mining to respond to the changing times and trends in the mining industry and to have appropriate policy guidelines to guide their effective and efficient operations;

(v) Regular education and training of key stakeholders such as local authorities, community leaders, miners, farmers, land owners etc. on the Mining \& Environmental Laws and associated regulations;

(vi) There is the need for collaborations between policy makers and training institutions such as University of Mines and Technology (UMaT) to produce and encourage graduates to team up and venture into SSM;

(vii) Adequately resourcing the regulatory institutions to provide effective and efficient monitoring and supervision of SSM operations;

(viii) Ghana Revenue Authority (GRA) can primarily introduce the tax stamps or flat rate tax payment to enable small scale miners pay taxes and royalties to raise revenue for government to aid in effective monitoring and supervision of the sector;

(ix) Serious collaboration among key stakeholders including Security Agencies, Regulatory Institutions, Traditional Authorities, Opinion Leaders, Farmers or landowners, Municipal/District assemblies among others to aggressively deal with illegal mining;

(x) Development of clear operational and environmental guidelines to help with effective and efficient supervision and monitoring of the SSM sector;

(xi) There is the need to establish training centres or model small scale mines to offer training to small scale miners in proper mining practices, proper support systems, ventilation, dewatering for underground operations, safe blasting practices, appropriate reclamation practices, and general occupational health and safety practices; and

(xii) The use of direct smelting (Sika Bukyia) technique and mercury retort should be promoted and made available on the market to avert the indiscriminate burning of gold amalgam in the open air.

\section{References}

Anon. (1994), "Environmental Protection Agency Act, 1994, Act 490", http://ghanatrade.gov .gh/ile/epa\%20laws/EPA-ACT-1994.pdf.

Accessed on: $1^{\text {st }}$ August, 2016.

Anon. (2006), "Minerals and Mining Laws 2006, Act 703", http://www.resourcegovernance. org/sites/default/files/Minerals\%20and\%20Mini $n$ g\%20Act\%20703\%20Ghana.pdf. Accessed on: $1^{\text {st }}$ August, 2016.

Anon. (2010), "Minerals Commission Ghana, 25 Years of Existence 1984-2009: Promoting and Regulating the Mining Industry for National Development - The Role of the Minerals Commission", Silver Jubilee Journal, 83 pp.

Anon. (2016a), "Ministry of Mines and Natural Resources: About the Ministry", http://www. mlnr.gov.gh/index.php/about-us. Accessed on: $1^{\text {st }}$ August, 2016.

Anon. (2016b), "Minerals Commission", http:// www.ghana-mining.org/ghanaims/MineralsCo mmission/tabid/155/Default.aspx. Accessed on: $1^{\text {st }}$ August, 2016.

Anon. (2016c), "Environmental Protection Agency", http://www.epa.gov.gh/epa/about. Accessed on: $1^{\text {st }}$ August, 2016.

Anon. (2016d), "Geological Survey Department", http://www.ghana-mining.org/ghanaims/Instit utions/GeologicalSurveyDepartmentGSD/tabid/ 156/Default.aspx. Accessed on: $1^{\text {st }}$ August, 2016.

Anon. (2016e), "Precious Minerals Marketing Company", http://pmmcghana.com/about-us/. Accessed on: $1^{\text {st }}$ August, 2016.

Anon. (2016f), "Water Resources Commission: About WRC", http://www.wrc-gh.org/. Accessed on: 1 August, 2016.

Anon. (2016g), "The Forestry Commission of Ghana", http://www.fcghana.org/page.php? page $=46 \&$ section $=22 \&$ typ $=1$. Accessed on: $1^{\text {st }}$ August, 2016.

Bryman, R. (2008), Social Research Methods, (3 ${ }^{\text {rd }}$ edition), Oxford University Press: Oxford, pp. $273-293$.

Eshun, P. A. (2005), "Sustainable Small scale Gold Mining in Ghana - Setting and Strategies for Rural Empowerment", In: Marker, B. R., Petterson, M. G. \& McEvoy, F. (eds) 2005, Sustainable Mineral Operations in the Developing World, Geological Society, London, Special Publications, 250, $61-72$. 
Pallant, J. (2007), SPSS Survival Manual: A Step by Step Guide to Data Analysis using SPSS for Windows Version 15 ( $^{\text {rd }}$ edition) Berkshire, England: Open University Press, 333 pp.

\section{Authors}

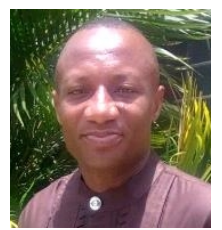

Peter Arroja Eshun obtained his BSc (Hons), PgD, MPhil and PhD degrees in Mining Engineering from the University of Mines and Technology (UMaT), Tarkwa. $\mathrm{He}$ is currently an Associate Professor of Mining Engineering at UMaT. His research interest is in the areas of Mine Economic and Financial Evaluation, Environmental Management, Socioeconomic Impact Assessment, Mine Feasibility Studies, and Small Scale Mining. He is a member of the Society of Mining Professors (SOMP), Society for Mining, Metallurgy and Exploration (SME), Canadian Institute of Mining and Mineral Engineers (CIM), and National Society of Black Engineers (NSBE).

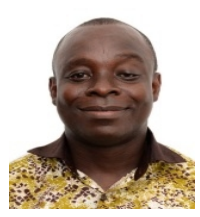

Ernest Okyere is a Mining Engineer, holds a Master of Science degree in Mining Engineering from the University of Mines and Technology (UMaT), Ghana and a Master in Business Administration from the University of Leicester, School of Management, in the United Kingdom. His research interest is in the areas of Mineral Policy and Conflict Resolution. 